http://dx.doi.org/10.4314/ejotmas.v7i1-2.13

\title{
NIGERIA'S CULTURAL POLICY IMPLEMENTATION: SUSTAINING CULTURAL DIVERSITY THROUGH CULTURAL RESOURCE MANAGEMENT
}

\author{
*Elizabeth O. BEN-IHEANACHO, Ph.D.
}

\begin{abstract}
Nigeria is one of the few African countries with a written cultural policy as well as government established and funded institutions charged with the implementations of this policy. This article interrogates the implementation of the tenets of the policy, given Nigeria's cultural diversity and the growing demand for tangible, verifiable economic indices of the contributions of the culture sector to both internally generated revenue (IGR) and the gross domestic product (GDP) of the nation. It suggests the need to expand the traditional understanding of cultural resource as land, labour and capital to embrace diverse forms of 'soft' cultural capital as assets whose management is critical to individual, community and national economic empowerment. The paper concludes with suggestions on strategies and best practices to enhance Nigeria's creative economy as integral evidence of continuing implementation of the cultural policy.
\end{abstract}

Keywords: Cultural policy, Cultural resource management, Cultural diversity, Creative economy

\section{Introduction}

A nation's cultural policy can be said to be the government actions, law and programmes that regulate, protect, encourage and financially (or otherwise) support activities related to the arts and creative sectors such as painting, sculpture, music, dance, literature and film making, among others; and culture which may involve activities related to language, heritage and diversity. It is "the expression of the government's willingness to adopt and implement a set of coherent principles, objectives and means to protect and foster its country's cultural expression" (Joseph and Rene 1). The centrality of a country's cultural policy to its development is akin to its national ideology and "provides the closest set of ideas and objectives that can shape the

*Elizabeth O. BEN-IHEANACHO, Ph.D. is of the Research and Documentation Unit, National Council for Arts and Culture, Abuja, Nigeria 
country's political and social procedure and set the character of...national culture" (Mazrui 9). Nigeria is one of the few African countries with a written cultural policy inaugurated in 1988 which has fully established government institutions, parameters and linkages to ensure systemic approach to cultural administration and implementation of the Cultural Policy for Nigeria. However, Asiwaju has noted the disconnect between the promulgation of Nigeria's cultural policy and its implementation (3). He explained this disconnect as a carryover of the tendency on the part of development planners to separate economic growth from cultural dimensions with the erroneous assumption that economic growth is a pre-requisite for other forms of development(4). This limiting understanding of the term 'development' as a quantitative index, marginalizes full appreciation of the qualitative imperatives and social values which is primarily the realm of culture in society; being man centered as its initial concern and ultimate goal.

Thus, in a nation constantly propelled by cold cash determined sectoral significance, the immediate lack of tangible, traceable contributions of the culture sector to the nation's internally generated revenue (IGR) and overall gross domestic product (GDP) has continued to plague and consign the sector to an 'alternative' source to the mono product driven national economy. Further, this disposition has led to the unwholesome trend whereby the culture sector and its activities have often been traditionally dismissed as unserious, mere entertainment, wasteful jamboree and undeserving of adequate government expenditure and funding. Clearly, such willful discrimination and the national disinclination to integrate existing traditional cultural spaces and indigenous assets into the quest for contemporary roadmap for national development result in the fallacy of underdevelopment which in turn leads to indiscriminate importation of foreign cultures and development models while marginalizing until the recently contributions of home grown varieties such as Nollywood, the fashion industry and visual arts. Hence, this paper anchors its conceptual framework on the management of cultural resources as a necessary strategy to restore community confidence in the relevance of shared cultural history and heritage to contemporary economic empowerment and overall social wellness.

\section{Nigeria's Cultural Policy and Nigeria's Cultural Diversity}

The Cultural Policy for Nigeria which has its root in resolutions arising from the inter- governmental conference on Cultural Policies held in Mexico in 1982, also signed into continental and global objectives, parameters and principles. One of these is the Cultural Charter which is based on the recognition of the cultural diversity and national identity 
of Africa in general and Nigeria specific to our discourse. Consequently, one of the clearly stated objectives of the policy, is to "evolve from our plurality, a national culture, the stamp of which will be reflected in Africa and world affairs" (Aig-Imoukhuede 13). UNESCO describes cultural diversity as the quality of diverse or different cultures as opposed to monoculture or a homogenization of cultures. It implies the variety of human societies or cultures in a specific region. Finally, cultural diversity also refers to having different cultures within a given space, implying respect for each other's differences (18).

Cultural diversity can be quantified through the number of languages spoken within the specific cultural space as well as by the distinctive nature of cultural goods, services and activities undertaken as vehicles of identity, value and meaning within this region as artistic expressions of cultural diversity. Nigeria, often called the giant of Africa, is the world's most populous black nation with an estimated landmass of 923,768 sq kilometers, a population of 195 million, 257 to 400 ethnic groups and about 520 linguistic communities. Clearly, Nigeria can be said to be a haven of cultural diversity; the richness of its diversity must be seen and harnessed as cultural capital and heritage resource. Nigeria's cultural diversity finds expression in various forms that together, create the distinct multifaceted plumage of unity in diversity. One of these is the array of traditional dressing associated with the different ethnic groups. Beyond mere covering of human nakedness, dresses connote "the power of cloth as a symbol of continuing social relations and identities in the face of uncertainty and death"(Weiner 178-183). Utoh-Ezeajugh asserts that dress is a distinguishing hallmark for each ethnic group and a form of non-verbal communication which gives mental clues to a person's social identity. In Nigeria, it is safe to say that the various traditional dresses, associated with the different ethnic groups, highlight our cultural diversity (22).

Nigeria's ethnic plurality has a rich potpourri of linguistic diversity which must be evaluated as a form of cultural capital from the point of language being a speech community (Yusuf 73). Whether these languages are active, endangered or disappearing, the close to 520 indigenous languages of Nigeria and its vibrant pidgin should be seen as mechanisms for increasing language growth using modern mass media including the nascent Nigerian film industry, aka, Nollywood and dedicated productions in indigenous languages, as well as the flourishing of Nigerian pidgin as a device for facilitating and preserving linguistic diversity and home grown idioms exhibiting vitality and a capacity for heritage preservation, promotion and economic versatility. An often overlooked indicator of Nigeria's cultural diversity is its indigenous culinary tradition and array of mouth-watering food and cuisines. The types and varieties of food available to a nation are 
determined by its ecological factor. Hence, the Savannah of Northern Nigeria is well disposed to grains production. Consequently, the culinary tradition arising from the dominant ecology is responsible for the predominance of grain based meals, snacks and drinks such as Tuwondawa/Masara/Shinkafa; Alkaki, Dankwa and Kulikuli; Kunun Aya, Kunun Gyada, and Kunun Zaki, etc. Conversely, the Southern part of Nigeria is characterized by the lush rain forest conducive to the growing of tubers, leafy greens, sea food and aquatic life. Therefore, the culinary delights of this geographical area of the country boasts of traditional soups such as Afang, Edikaikong, Oha, and Onugbu; snacks such as abacha, Okpa, and Ukwa. It is equally important to note that the tweaking in the production process of a common denominator food item results in different culinary ingredients. Cassava is one such food item in Nigeria's culinary listing. Among the Igbo ethnic group it is fermented to produce Akpu, fried into Garri, sun dried by the Urhobo into Kpokpogarri while the starch derived in processing cassava serves as a morsel among the Urhobo and Itshekiri. When cassava is sliced into chips, it is the basic ingredient for one of Nigeria's highly reputed culinary delights, abacha; of no mean value to indigenes of Enugu State.

The diversity of traditional festivals associated with the different ethnic groups of the country is also an indication of the cultural diversity status of Nigeria. A festival may be said to be an event periodically celebrated by a community and centering on some characteristic aspect of their communal life; be it religion, occupation or philosophy. Consequently, there are many types of festivals as there are celebratory reasons across the various communities in Nigeria. As the sum expression of a people's way of life, festivals incorporate diverse forms of creative enterprise and art forms. Also, most festivals in Nigeria are calendar events used to usher in new seasons, celebrate rites of passage and form links to worship. Hence, festivals remain authentic communal expressions as diverse as the numerous communities that are the principal owners. Famous among Nigeria's varied traditional festivals are New Yam festival among the Igbos; the Durbar festival of the Muslim North, the Eyo Masquerade festival of Lagos State, the Osun Osogbo festival of Osun worshippers of Yorubaland, and the Argungu fishing festival, arguably the most impressive professional festival of Nigeria. It is significant that the cultural policy for Nigeria recognized festivals as authentic factors of communal interaction and cohesion autonomous to their primary owner localities. Article 7.8 sub article (a) and (b) of the Cultural Policy of Nigeria state that;

The state shall: 
a) Promote traditional festivals in order to preserve them in situ so that they may continue to be factors of communal interaction and cohesion in their localities and develop interaction of larger national and international dimensions;

b) Promote Arts Festivals at the Federal, State and Local Government levels for the purpose of discovering talents, developing skills and promote creativity in the arts.

However, in view of the federal structure and the pluralistic nature of the Nigerian society, a decentralized approach to the administration of culture continues to defer to systemic cultural diversity. Consequently even with the implementation of the only Federal Government fully funded cultural festival, the National Festival for Arts and Culture (NAFEST), the 36 States of the Federation and the FCT which are the principal stakeholders, exercise extensive autonomy in their participation, under the coordination of the National Council for Arts and Culture, the Federal parastatal that is charged with the promotion, preservation and presentation of Nigeria's culture. Thus

the 36 States of the Federation and the Federal Capital Territory are the custodians of the arts and culture of the country as the traditional repository of these cultural manifestations are often resident in the various Local Government Areas of the nation at the grassroot levels. In addition, the States Councils for Arts and Culture / History and Culture Bureaux were the median vehicles for transmitting and packaging these cultural performances in a manner acceptable and responsive to the sensibilities of the State and the nation at large (Maidugu 33).

What this means for the administration of culture in Nigeria, is that not much dynamism has been infused to the implementation of the Cultural Policy since the stipulated guidelines, ab initio, postulate the preservation and "in situ" presentation of expressions of our national heritage even when on a global platform. It is the determination to upturn this limiting interpretation that draws impetus from cultural resources management.

Further, it is needful that the economic imperative be married into the execution of the Cultural Policy for Nigeria. This policy in Part III titled Administration and Finance especially Article 10.3 sub article 1 (a), (b), (c) \& (d) rest the burden of financing and funding of cultural 
activities largely on the government. When non-governmental organizations are invited into the business of cultural resource management, the policy determinants are guided into "voluntary financial contributions which shall be tax-deductible (Bello 204; emphasis mine). Regrettably, the National Endowment for the Arts, of which sub article (c) concerns itself and which was promulgated by Decree 52 of 1991, is yet to be activated thus further denying the arts and broad spectrum of cultural activities, much needed funds and financing networks. Consequently, much of cultural administration of the diverse resources of the nation by the established government parastatals and agencies is guided by and dependent solely on government budgetary allocation.

Cultural Resource Management and Nigerian Cultural Diversity The U.S National Park Service define cultural resource as the physical evidence or place of past human activity, site, object, landscape, structure or natural features of significance to a group of people traditionally associated with the said location of past human activity, archaeological resources, cultural landscapes and museum objects (n.pag). Using this rather narrow definition, examples of cultural resources in Nigeria include the Sukur wall of Adamawa State, the Kaduna NOK sites, the Benin Moat of Edo State, the Kwatarkwashi hill of Zamfara State, Olumo Rock of Ogun State and Taruga iron smelting site of FCT, among others. For the purposes of this paper, however, cultural resources would be used as an embracing term that encapsulates all cultural assets available to any community and which could be manipulated to yield economic imperatives to the general well being of members of the community. To this focus, in so far as festivals, food fairs, traditional textiles and fashion accessories etc can be promoted as cultural assets whose domestic consumption and export possibilities can promote the mobility of those items as economic deliverables, they are considered cultural resource whose management for quantifiable contributions to the nation's GDP, is the thrust of concern.

Cultural resource management, therefore, is to be seen as the vocation of managing identified cultural resources; be they sites, artifacts, relics, arts and heritage associated with an identified location of historical and social significance to its primary owner. Further, it is the targeted strategy of mainstreaming the 'software' of a people's traditional practice, artistic expressions, shared communal spaces and cultural heritage towards contemporary currency, continuing patronage and improved visibility of human creativity as the basis of collective economic empowerment. Cultural resource management would appear 
to be a bridge between traditional and modern heritage management of inherited community cultural identifiers and individual creativity for economic well-being. traditional resources are exemplified by archaeological and historic material remains as well as intangible heritage such as festivals while modern resource heritage fall within the spectrum listed by Howkin to include the arts, cultural goods and services, toys, games, research, and development design, media and all kinds of creativity whether expressed in art or innovation to increase or add value. Therefore, the expanded application of the idea of cultural resource management goes beyond the traditional resources of land, labour, and capital to embrace advertising, arts, crafts, cuisines, fashion, film, music, performances, radio, television, galleries, museums, and all such creative activities concerned with the generation and exploitation of knowledge and information(n.pag). The sterling performance of nascent Nigerian film industry also called Nollywood and the high net worth visibility of Nigerian visual arts, illustrate.

In pursuance of the veritable submission that human creativity is the ultimate economic resource (Florida xiii) we now turn to suggestions on how cultural resource management of Nigeria's rich and diverse creative expressions can best be strategically harnessed to contribute the deepening of the creative economy of the nation. It must be noted that administrators of culture have been pressed to establish the linkage between cultural activities, economic empowerment and deliverable national development through the years. For example, the National Festival for Arts and Culture, unarguably the most aggregate and visible national cultural festival will suffice. Profiling the twenty fifth edition of the festival, the management of National Council for Arts and Culture, the host agency of the festival, wrote:

Over the years, the National Festival of Arts and Culture (NAFEST) has consistently projected the aesthetic and inherent communal wholeness of our traditional and living cultural practices. Hence, NAFEST 2011 is designed to build on this tradition to stimulate abundant potentials in our cultural industries with a view to harnessing them for National Development. It also aims at using our cultural industries to economically empower, create wealth and highlight this vital element that make us one people, one nation with a common destiny. (Programme of Event NAFEST 17) 


\section{Cultural Resources Management: Suggested Strategies towards Economic Deliverables}

\section{Identification and Cataloguing of Cultural Assets}

The essential first step will help answer basic question for the owner community and coordinating committee at all levels. These Frequently Ask Questions are - Where are the sites and shared community spaces and experiences? What is their significance? How best can they be protected from decay and vandalization by all interested parties at all levels? How best can they be promoted and harnessed for continuing visibility and patronage? Simplistic as this basic step might seem, on it hinges greater patronage, community and external investor buy into the assets. Important, too, each owner community decides which asset it wants to promote and how. Ultimately, they are the frontline beneficiaries of all accruing cultural economics.

\section{Sensitization and Awareness Creation}

This phase is the consequence of the prior. Once identified and properly catalogued, the next stage is how to reach multi-layer users beginning with the owner community, tourists outside the immediate owner community, enlightened users such as research driven members of the academia and even students on education related excursions, etc. The participant possessor committee of stakeholders must ensure that awareness of the contributive value of this cultural asset is bought into by members of the owner community who are first line beneficiaries of accruing benefits and therefore participants/ promoters of the patronage of their own heritage as well as empowered contributors to their own economy. Therefore, the operational byline should be Attention, Attraction and Patronage.

\section{Protection and Promotion of Identified Cultural Assets}

It has been the lot of many traditional, cultural assets to suffer willful destruction by misguided and unenlightened members of the owner community for diverse reasons ranging from religious fanaticism to land grab and territorial aggrandizement. Therefore, a meaningful economic empowerment driven cultural resource management strategy must necessarily device forms of protection and contemporary preservation of assets as well as strategies for continuing awareness, patronage, presentation of ancient history and traditional practices through modern media and collective lore including new fangled festivals and carnivals. The newly inaugurated Drum Festival of Abeokuta by the Ogun State Government and the Ohueje Ohinonyi Festival of Igbiraland driven by private stakeholders come to mind as possible models for adaptation. 


\section{Thinking outside the Box}

Cultural resource managers in Nigeria must gird their mind into a creative broadband that inclines them to be innovative outside-thebox thinkers; primed to raise the bar of all imaginable challenges to their determination to streamline the past into the present. Workers in the sector at all level must of necessity be challenged to proffer alternative solutions and be ready to walk the less trodden path. Consequently, their disposition is as important as their taking cognisance of some of the challenges which may wreck their task accomplishment. These challenges include: resistance to new ideas especially as evidence of mistrust of the purveyor of the new concept as well as the unwillingness of resource owners to divulge associated myths and sacred secrets to a central body outside their immediate family/ community ownership. An equally ominous challenge remains the ever present ogre of inadequate funding and the paucity of stakeholders' goodwill to support an ear marked project through sponsorship and partnership.

\section{Conclusion}

This paper has undertaken an analysis of the centrality of cultural resource management to the continuing holistic implementation of the Cultural Policy for Nigeria. The evaluation is premised on an expansion of the traditional frontiers of cultural resources of land, archaeology and anthropological remains, to an inclusive persuasion of human creative endeavours and the innovative products of human ideas adding value to heritage capable of delivering economic benefits to individuals and their communities. Hence, against the prevalent dispensation of the demand that the culture sector yields tangible proof of its economic potentials towards national development, this paper presents cultural resource management as a viable process to enhance the economic contributions of cultural assets to the internally generated revenue of the host community and the nation's gross domestic product grid, at large. Further, it serves as a targeted rescue strategy towards salvaging the long disenfranchised sector from the economic and social peripheries of national life to which it has long been consigned. Finally, it has been the persuasion of this study that true national development, being all about the total wellbeing of humans in society, can only flourish with the recognition that the rural environment which is the traditional habitat of most of the resources to be effectively managed for collective national patrimony, have a great deal to offer from its cultural pool if an inclusive, inward developmental module is pursued to a beneficial purpose. 


\section{Works Cited}

Aig-Imoukhuede, Frank. "The National Cultural Policy: Parameters, Linkages and Strategies - An Assessment." Culture and Decision Making in Nigeria. Ed. Sule Bello. Lagos: National Council for Arts and Culture, 1991. Print.

Asiwaju, Garba. "Imperatives and Problems of Policy Formulation in the Cultural Sector." Culture and Decision Making in Nigeria. Ed. Sule Bello. Lagos: National Council for Arts and Culture, 1991. Print.

Florida, Richard. The Rise of the Creative Class and How it's Transforming Work, Leisure and Everyday Life. New York: N.Y Basic Books,1992. Print.

Howkins, John. The Creative Economy. New York : Penguim Group, 2001. Print.

Joseph J. and Rene, L. (1999). Political and Social Affairs Division. Ontario: Canadian Council of Arts. Print.

Maidugu, M.M. "Operational Scope and Strategy of Abuja Carnival." Ed. Ahmed Yerima and

Elizabeth Ben-Iheanacho. Abuja Carnival: The Story. Abuja: Heritage 43 Books, 2009. Print.

Mazrui, Ali cited by Aig- Imoukhuede. "The National Cultural Policy: Parameters, Linkages and

Strategies - An Assessment. Culture and Decision Making in Nigeria. Ed. Sule Bello. Lagos: National Council for Arts and Culture, 1991. Print.

Programme of Events for 25th National Festival of Arts and Culture (NAFEST) on the Theme "Nigerian Traditional Music: A Vehicle for Economic Transformation and Unity" held between Saturday 22nd - Saturday 29th October 2011 at the U.J. Esuene Township Stadium, Calabar. Print.

UNESCO. "UNESCO Universal Declaration on Cultural Diversity." Web. 24 July 2018. <http://unesdoc.unesco.org/images/0012/ 001271/127162e.pdf>.

Utoh- Ezeajugh, Tracie. "Traditional Nigerian Dress Culture: A Historical Overview." Ed. Rasaki Ojo Bakare and Barclays F. Ayakoroma. Dress Culture and National Development. Ibadan: Kraft Books, 2011. Print.

U.S National Park Services. "Cultural Resources." Web 15 July 2018. <https://www.nps.gov/acad/learn/management/ rm_culturalresources.htm>.

Weiner, Annette Barbara. "Inalienable Wealth." American Ethnologist 12.2 (1986): 178-183. Print. 
Yusuf, Ore. "Disappearing Languages of the Middle Belt: Step to Safeguard." Ed. Lizzy Ihezue O. Osuji. Proceedings of the National Workshop on the Best Practices to Safeguard Endangered Nigerian Languages. Abuja: UNESCO, n.d. Print. 